\title{
Refleksi Nalar Budaya Pendidikan Islam Dan Dampaknya Dalam Perilaku Sosial Keagamaan
}

\author{
Ahmad Ali Riyadi \\ Institut Agama Islam Tribakti Kediri \\ ahmadaliriyadi@gmail.com
}

\begin{abstract}
Islamic education approaches religion as a social framework by carrying out critical reflections on social problems faced by society, both macro and micro, then building a change strategy (theory) that is practised in the form of action change (practice). In praxis, education builds a character's culture of educational behaviour as values and behavioural characters. This study discusses the important role of Islamic educational institutions as agents of the development of science that have an impact on cultural social religious behavior. The results of this study indicate education in the formation of culture is an indoctrination as a process that is carried out based on a value system to instil certain ideas, attitudes, systems of thought, behaviour and beliefs. This practice is often distinguished from education because, in this act, an indoctrinated person is expected not to question or critically test the doctrine that has been learned.
\end{abstract}

Keywords: Cultural Reason, Islamic Education, Religious Social Behavior

\begin{abstract}
Abstrak
Pendidikan Islam mendekati agama sebagai kerangka sosial dengan melakukan refleksi kritis atas problem sosial yang dihadapi masyarakat, baik yang bersifat makro maupun mikro, kemudian membangun strategi perubahan (teori) yang dipraksiskan dalam bentuk aksi perubahan (praktik). Secara praksis pendidikan membangun budaya karakter perilaku pelaku pendidikan sebagai nilai dan karakter perilaku. Kajian ini mendiskusikan peran penting lembaga pendidikan Islam sebagai agen pengembangan ilmu pengetahuan yang berdampak pada budaya perilaku sosial keagamaan. Hasil penelitian ini menunjukkan pendidikan dalam pembentukan budaya merupakan indoktrinasi sebagai sebuah proses yang dilakukan berdasarkan satu sistem nilai untuk menanamkan gagasan, sikap, sistem berpikir, perilaku dan kepercayaan tertentu. Praktik ini seringkali dibedakan dari pendidikan karena dalam tindakan ini, seseorang yang diindoktrinasi diharapkan untuk tidak mempertanyakan atau secara kritis menguji doktrin yang telah dipelajari.
\end{abstract}

Kata Kunci: Nalar Budaya, Pendidikan Islam, dan Perilaku Sosial Keagamaan 


\section{Pendahuluan}

Kata nalar dimaknai sebagai epistem suatu bangunan keilmuan. Kaitannya dengan pendidikan, kata nalar mempunyai implikasi bahwa proses munculnya lembaga pendidikan dianggap sebagai himpunan-himpunan yang dipaksakan secara tidak sadar sebagai akibat kajian keislaman yang berlangsung di masyarakat. Kajian ini menjadi bentuk epistem atau himpunanhimpunan aturan yang menjadi kaidah berpikir yang diberikan oleh budaya bagi penganutnya sebagai landasan untuk memperoleh pengetahuan. ${ }^{1}$ Maka dari itu, lembaga-lembaga pendidikan yang ada merupakan model kajian Islam yang berdampak pada penyampaian agama secara sistematis. Model pendidikan inilah yang menjadi budaya keilmuan yang heterogen sesuai dengan model kajian ke-Islam-an masing-masing, sehingga dalam faktanya ditemukan adanya model pendidikan Islam yang beragam.

Pendidikan Islam sebagai proses pembumian ajaran Islam agarumat dapat mengembangkan daya pikir, rasa, dan tindakannya sesuai dengan ajaran Islam, maka upaya pengembangan pendidikan Islam tidak bisa dilepaskan dari landasan orbitnya yaitu Islam itu sendiri, apalagi aktifitas pendidikan merupakan bagian tak terpisahkan dari ajaran agama. ${ }^{2}$

${ }^{1}$ Lukman S. Thahir, Harun Nasution (19191998): Interpretasi Nalar Theologis dalam Islam (Yogyakarta: Disertasi PPs. IAIN Sunan Kalijaga - Yogyakarta, 2003), h. 12.

$\begin{array}{ccc}2 & \text { Kasdi, Abdurrahman. } & \\ \text { undamentalisme Islam Timur Tengah: Aka }\end{array}$
Di Indonesia, Agama Islam selalu didialogkan dengan budaya. Bagi salah satu firqoh di Indonesia menyatakan Islam yang khas ala Indonesia, gabungan nilai Islam teologis dengan nilainilai tradisi lokal, budaya, dan adat istiadat di Tanah Air. Dalam konteks ini, budaya suatu daerah atau negara tertentu menempati posisi yang setara dengan budaya Arab dalam menyerap dan menjalankan ajaran Islam. Suatu tradisi Islam Nusantara menunjukkan suatu tradisi Islam dari berbagai daerah di Indonesia yang melambangkan kebudayaan Islam dari daerah tersebut.

Berdasarkan pembahasan di atas, menunjukkan pendidikan Islam pun tidak bisa dilepaskan dengan budaya. Budaya pendidikan tidak ubahnya sebuah ideologi yang dideterminasi oleh aktor yang mengendalikan. Bila budaya pendidikan disampaikan sebagai sesuatu yang transformatif dan progresif, maka akan tampil sebagai agen perubahan. Begitu pula sebaliknya jika budaya pendidikan disampaikan sebagai sesuatu yang kaku maka ia akan tampil sebagai agen kebekuan. ${ }^{3}$ Sebaliknya, pendidikan Islam yang didesain untuk mentranformasikan nilai-nilai pembaharuan, maka akan berdampak pada pembaharuan dan perkembangan kualitas sumber daya manusia (SDM).

Sejatinya, prinsip dasar pendidikan sebagai garda terdepan untuk

Teologi. Kritik Wacana dan Politisasi Agama". Jurnal Tashwirul Afar. Lakpesdan NU Jakarta. No. 3., h.27

${ }^{3}$ Very Verdiansyah, Islam Emansipatoris: Menafsir Agama Untuk Praksis (Pembebasan, Jakarta: P3M, 2004), h. 28. 
usaha transformasi yang revolusioner bagi perubahan sosial, sehingga pendidikan sebenarnya anti status quo yang melanggengkan kemandegan. Persoalannya adalah bagaimana nalar budaya yang dibangun oleh pendidikan Islam yang secara tidak langsung dalam pembentukan sistem sosial dan keagamaan. Dalam hal ini, satu dalih penting adalah pendidikan sangat menentukan perilaku sosial keagamaan ke depannya.

\section{Metode}

Penelitian ini menggunakan metode studi kepustakaan atau Library Research. Studi kepustakaan adalah teknik pengumpulan data dengan mengadakan studi penelaahan terhadap buku-buku, literatur-literatur, catatancatatan, dan laporan-laporan yang ada hubungannya dengan masalah yang dipecahkan. Artikel ini memanfaatkan jurnal, bahan-bahan dan informasi yang relevan untuk dikumpulkan, dibaca dan dikaji, dicatat sebagai pedoman ataupun sumber referensi. Metode studi pustaka dalam artikel ini dapat dijadikan sebagai data dan sumber data mengenai topik masalah. Library Research ini bertujuan untuk memberikan gambaran kepada pembaca, tentang topik masalah yang sedang diteliti.

\section{Hasil Penelitian dan Pembahasan} Nalar Budaya Transkultural

Transkultural dimaknai sebagai pemahaman budaya yang terbentuk dari budaya impor yang menggantikan budaya lokal, bahkan cenderung menutup diri terhadap budaya setempat. Dalam hal ini tidak terkecuali budaya yang merupakan hasil pemahaman atau tafsir suatu agama. Ciri khas budaya impor ini merupakan budaya idola yang menutup kesempatan budaya lainnya untuk berpartisipasi. ${ }^{4}$

Ciri yang lainnya adalah pemahaman keagamaan berdasarkan himpunan aturan-aturan dan kaidah berpikir yang diberikan oleh budaya, baik budaya Arab maupun non-Arab, bagi penganutnya sebagai landasan untuk memperoleh pengetahuan. Himpunan-himpunan atau aturan-aturan yang sudah ditentukan itu dipaksakan secara tidak sadar sebagai kerangka pengetahuan. Dengan demikian identitas keagamaan semakin dipersempit dalam lingkaran pemaknaan yang sudah terkodifikasi sedemikian rupa. Teks-teks keagamaan menjadi pemberi stempel yang dapat memberikan legalitas di pentas sosial atas nama agama. Produk pemikirannya senantiasa mengandaikan adanya pijakan yang menunjuk pada sumber yang dianggap rasional yang selalu dianggap membawa kebenaran dan sebaliknya hal yang baru seringkali disebut pembawa bid'ah dan kemurtadan (kekafiran). Pola pandang

${ }^{4}$ Ali Muhtarom, Ideologi dan Lembaga Pendidikan Islam Transnasional di Indonesia (Jakarta; Zahir Publishing, 2019), h. 20. 
semacam ini tentu menjadi hambatan serius dalam rangka melakukan perubahan pada tataran praksis-teologis karena ketergantungan pada masa lalu begitu kuat dan masa lalu itu diyakini sebagai lokomotif perubahan.

Seringkali fakta nalar transkultural ini diimplementasikan dalam pemikiran purifikasi agama. Tema ini muncul dilatarbelakangi oleh semakin merebaknya kalangan agamawan yang memegang teguh relasi agama dan budaya lokal yang keberadaannya dianggap dapat mengancam keberadaan agama itu sendiri. Inti ajaran purifikasi adalah kembalinya pemahaman agama berdasarkan landasan normatif dari berbagai model interpretasi dan pelaku keagamaan bercorak lokal di luar ajaran normatif. 5 Purifikasi juga memandang tradisi sebagai ajaran normatif yangn berasal dari Tuhan yang tentunya harus dibedakan dengan budaya di mana ajaran itu dipahami.

Dalam praktek keagamaan berdasarkan purifikasi agama para pelakunya terjebak dalam pandangan bahwa kebudayaan Arab Wahabi menjadi idola dalam praktek keagamaan. Apakah model pemahaman agama ini salah? Tentu tidak ada yang salah dalam mengadaptasi kebudayaan Arab Wahabi untuk mengekspresikan keberagamaan seseorang. Yang menjadi masalah adalah menggunakan ekspresi kearaban atau

\footnotetext{
5Muhammad Abed al-Jabiri, Post Tradisionalisme Islam, penerj. Ahmad Baso (Yogyakarta; LKiS, 2006), h. 60

'Imdadun Rahman dkk.,"Islam Pribumi: Mencari Wajah Islam Indonesia," dalam Tashwirul Afkar Edisi 14 Tahun 2001, h. 9.
}

budaya impor sebagai ekspresi tunggal yang dianggap paling absah dalam beragama dan berkebudayaan sehingga ekspresi kearaban menjadi lebih dominan bahkan menghegemoni budaya dan tradisi lainnya. Akibatnya tidak hanya mengakibatkan tradisi tersebut pudar akan tetapi juga akan hilang dan mati. Lebih radikal lagi jika budaya setempat yang sudah berkembang lebih dahulu dan menjadi nilai masyarakat setempat kemudian dianggap sesat, musyrik dan bid'ah tanpa harus memandang kerangka kesejarahan sosial masyarakat setempat. Sudah pasti langkah ini merupakan sikap pembasmian ttradisi lokal yang selama ini diuri-uri dan dikembangkan para pemikir Islam diberbagai belahan dunia non-Arab. ${ }^{6}$

Bagi para penggagas purifikasi
agama, agama yang dicontoh
salafussolihin merupakan bentuk
keberagamaan yang paling benar dan ideal. Keunikan ekspresi keberagamaan masyarakat, baca non Arab, dicerca sebagai kejahilan modern yang jauh dari pemahaman agama yang benar, otentik dan asli. Agama di luar Arab dinilai kehilangan keasliannya semenjak ia mengakomodasi dan berakulturasi dengan budaya dan tuntunan lokal. ${ }^{7}$

Perilaku dan kerangka berpikir lebih menandakan tipe formalistik yang menunjukkan suatu model pemikiran yang mengutamakan peneguhan

${ }^{7}$ Abdul Mun'im DZ, “Mempertahankan Keragaman Budaya," dalam Tashwirul Afkar, Edisi No, 14 Tahun 2003, h. 7. 
ketaatan yang ketat pada format ajaranajaran agama. Dalam konteks sosialbudaya-politik, model ini menunjukkan perhatian terhadap suatu orientasi yang cenderung menopang masyarakat Islam yang dibayangkan, seperti maujudnya suatu sistem politik Islam, munculnya partai Islam, ekspresi simbolik idiom budaya Islam serta eksperimen sistem kemasysrakatan Islam. Oleh karena itu, pandangan ini lebih menekankan ideologisasi yang mengarah pada simbolisme keagamaan secara formal. Kuatnya formalisme agama ini kadangkala menjadi memunculkan resistensi terhadap dominasi budaya yang dianggap melemahkan Islam, khususnya dunia Barat yang lebih maju daripada dunia Islam. Akibatnya mereka melakukan peneguhan ideologi dan budaya mereka sendiri sebagai langkah untuk mengimbangi budaya orang lain, baca Barat dan non Arab Islam. ${ }^{8}$

Penggunaan terminologi yang mereka anggap Islami, doktrin keagamaan diterjemahkan bukan sekedar rumusan teologis akan tetapi juga suatu sistem keimanan dan tindakan sosial yang komprehensif dan eksklusif. Terdapat kecenderungan yang menunjukkan kurangnya minat mereka dalam pengembangan dan imlementasi pemikiran sosial atas suatu lingkungan kultural yang spesifik dan khas karena hal ini akan dkawatirkan dapat menghilangkan atau mereduksi identitas keimanan. Pemeliharaan kaum formalis terhadap bahasa otentik dari wahyu bukan saja menunjukkan kuatnya refleksi terhadap budaya skripturalisme, akan tetapi juga memperlihatkan kecenderungan mereka untuk menggunakan pendekatan literal dan tekstual dalam mengartikulasikan gagasan-gagasan sosial. Juga mereka memanfaatkan argumen-argumen yang sifatnya tradisionalistik dan fundamentalistik. Walaupun mereka lahir dari lingkungan modernis dan terdidik secara modern model Barat cara berpikir mereka tetap formalistik dan menekankan idiom-idiom keislaman. Dampaknya, mereka sangat kesulitan untuk menerima metodologi dan analisis yang bersumber dari khazanah ilmu-ilmu sosial Barat. Sikap kritis mereka terhadap segala sesuatu yang dianggap berada dalam pengaruh westernisasi adalah bagian dari peneguhan identitas keislaman yang dikhawatirkan dapat melemahkan Islam dalam menghadapi kemoderenan. ${ }^{9}$

Model pemahaman keagamaan seperti itu biasanya selalu mencurigai dan mengkritisi model pemahaman akulturasi agama dan budaya lokal dengan cara-cara konflik. Budaya yang di luar dirinya atau yang datang dari pemahaman orang lain dianggap sesat, bid'ah dan kurafat. Term ini merupakan istilah yang digunakan untuk menghilangkan dan mengidentifikasi 
budaya orang lain (outsider) sebagai pembatas antara ia (insider) dengan orang lain (outsider). Walhasil terjadilah konflik antar peradaban di mana salah satunya harus mengalah bahkan salah satunya harus dihilangkan demi eksistensi budaya dirinya sendiri dan menafikan budaya orang lain. ${ }^{10}$

Model pemahaman transkultural memunculkan berbagai model kajian Islam dan kelompok Islam garis keras yang lebih mengedepankan idealisasi syari'at. Kelompok Islam model ini biasanya tidak terlibat dalam kegiatan intelektual yang mencoba mengadaptasikan pesan-pesan agama dan makna Islam ke dalam kondisi sosial dipenghujung abad kedua puluh. Akan tetapi mereka perpandangan bahwa pesan-pesan dan makna kehidupan sudah jelas termaktub dalam kitab suci dan tradisi rasul yang hanya secara otomatis diterapkan dalam kehidupan tanpa harus melakukan interpretasi. Berbagai slogan yang berkembang dengan corak pemikirannya yang skripturalis radikal seperti kitab suci adalah kalam Ilahi yang harus dipahami secara literal, bahwa dalil normatif agama sudah menyediakan perangkat hukum dan doktrin halal haramnya bagi perilaku individu maupun masyarakat dan Islam mencakup seluruh aspek kehidupan manusia. Pemeliharaan kaum formalistik radikal terhadap bahasa otentik dari wahyu bukan saja menunjukkan kuatnya afeksi terhadap skripturalisme, akan tetapi juga memperlihatkan kecenderungan mereka untuk menggunakan pendekatan literal dan tekstual dalam menngartikulasikan gagasan-gagasan sosial politik.

Kelompok-kelompok Islam transkultural yang berkembang di Indonesia dapat dicermati secara kultural dan struktural, secara kultural mereka membentuk ormas-ormas Islam sebagai sayap perjuangan dakwah sedangkan secara struktural mereka membentuk partai politik untuk menyalurkan aspirasi mereka dan memperkuat jaringan dipemerintahan. Karakteristik kelompok ini lebih didasarkan pada corak keberagamaannya yang bersifat integralistik antara agama dan segala aspek kehidupan, sehingga kelompok ini lebih mengedepankan corak legal formal Islam secara total.

Secara sosiologis politis, kemunculan gerakan Islam di Indonesia disebabkan oleh dua faktor, faktor internal umat Islam. Faktor ini dilandasi oleh kondisi internal umat Islam sendiri yang dianggap telah terjadi penyimpangan norma-norma agama. Kehidupan sekuler dan pertautan aspek lokalitas yang sudah merasuk ke dalam kehidupan umat Islam dengan segala dampaknya mendorong mereka melakukan gerakan-gerakan kembali kepada otentitas Islam. Sikap ini ditopang oleh pemahaman agama yang totalistik dan formalistik, bersifat kaku dalam memahami teks-teks agama, dan merujuk 
totalitas perilaku Rasul di Makkah dan Madinah secara literal total. Oleh karena itu, identitas keagamaannya sangat literalistik, kaku dan cenderung menolak peruhan sosial. Mereka frustasi terhadap perubahan dunia yang begitu cepat, sementara respon Islam sangat lambat dan ketinggalan dibandingka dengan masyarakat Barat sekuler. Kedua, faktor eksternal di luar umat Islam. Faktor ini lebih ditekankan pada perlawanan terhadap kelompok lain, khususnya dunia Barat, yang telah menghegemoni dan terlalu ikut campur terhadap umat Islam. Umat Islam dianggap diperlakukan tidak adil oleh dunia Barat secara politik, sosial, budaya dan ekonomi, sehingga mereka harus mendeklarasikan perlawanan terhadap Barat. Dominasi Barat terhadap negaranegara Islam yang berlebihan dan tidak dalam kapasitasnya yang salig bekerja sama akan tetapi malah memojokkan dan memusuhi, yang pada akhirnya ketidakadilan Barat ini dilawan dengan aksi-aksi kekerasan. Reaksi ditunjukkan kelompok Islam radikal biasanya adalah melawan dengan kekerasan terhadap kepentingan-kepentingan Barat. Jihad menjadi simbol perlawanan yang efektif untuk menggerakkan perang melawan Barat. Kondisi ini menyebabkan permusuhan yang terus menerus antara Islam dan Barat. ${ }^{11}$

Dari faktor-faktor itu, secara umum ada beberapa karakter berkaitan dengan istilah Islam radikal; pertama, radikalisme merupakan respons terhadap kondisi yang berlangsung. Biasanya respons tersebut muncul dalam bentuk evaluasi, penolakan atau bahkan perlawanan. Masalah-masalah yang ditolak dapat berupa asumsi atau ide, lembaga atau nilai-nilai yang dapat dipandang bertanggungjawab terhadap keberlangsungan terhadap kondisi yang ditolak. Kedua, radikalisasi tidak berhenti pada upaya penolakan, melainkan terus berupaya mengganti tatanan tersebut dengan suatu bentuk tatanan lain. Ciri ini menunjukkan bahwa dalam radikalisasi terkandung suatu program atau pandangan dunia tersendiri. Kaum radikalis berupaya kuat untuk menjadikan tatanan terseut sebagai ganti dari tatanan yang sudah ada. Ketiga, kuatnya keyakinan kaum radikalis akan kebenaran program atau ideologi yang mereka bawa. Sikap ini pada saat yang sama dibarengi dengan penafian kebenaran dengan sistem lain yang akan diganti. Dalam gerakan sosial, keyakinan tentang kebenaran program atau filosofi sering dikombinasikan dengan cara-cara pencapaian yang mengatasnamakan nilai-nilai ideal seperti kerakyatan atau kemanusiaan. Saking kuatnya keyakinan ini dapat megakibatkan munculnya sikap emosional berlebihan yang menjurus pada kekerasan. ${ }^{12}$

12Zaki Mubarak, Genealogi Islam Radikal di Indonesia (Jakarta; LP3ES, 2009). h.25 
Oleh karena itu, tidak terlalu mengejutkan meskipun kadang-kadang menghawatirkan, bahwa dunia Islam kontemporer menyaksikan umat Islam yang mendasarkan seluruh kerangka kehidupan sosial, ekonomi, budaya dan politik pada ajaran Islam secara eksklusif tanpa menyadari keterbatasanketerbatasan dan kendala-kendala yang bakal muncul dalam prakteknya. Ekspresi-ekspresinya dapat ditemukan dalam istilah-istilah simbolik yang dewasa ini populer dengan revivalismen Islam, kebangkitan Islam, revolusi Islam atau fundamentalisme Islam.

\section{Nalar Budaya Akulturatif}

Nalar akulturatif sebagai

aksentuasi bahwa makna iman dan peribadatan lebih penting daripada formalitas dan simbolisme keagamaan serta ketaatan yang bersifat literal kepada teks normatif wahyu Tuhan. Pesan-pesan Tuhan lewat teks normatif yang mengandung esensi abadi dan universal ditafsirkan kembali berdasakan runtut dan rentang waktu generasi kaum muslimin serta mengkotekstualisasikannya dengan kondisi-kondisi sosial yang berlaku pada masanya. Refleksi kelompok ini pada dasarnya adalah melakukan upaya yang sinifikan terhadap pemikiran dan orientasi sosial yang menekankan manifestasi substansial dari nilai-nilai Islam aktivitas sosial. Bukan pada penampilan akan tetapi juga dalam format pemikiran dan gerakan sosial mereka. Bagi kelompok ini eksistensi dan artikulasi nilai-nilai Islam yang intrinsik dalam iklim sosial lebih penting dan sangat memadai untuk mengembangkan Islamisasi dalam wadah kultural masyarakat. ${ }^{13}$ Proses kulturalisasi telah melahirkan kompetisi di antara berbagai kekuatan kultural dan Islam adalah salah satu kekuatan yang bersaing itu. Agar supaya Islam dapat memenangkan persaingan itu proses Islamisasi haruslah mengambil bentuk kulturalisasi bukannya formalisasi. Gerakan Islam sebaliknya menjadi gerakan budaya daripada menjadi gerakan formalisasi.

Gerakan akulturatif dalam dunia pendidikan di Indonesia dapat dicermati adanya berbagai lembaga pendidikan yang muncul mengakar di tengah masyarakat Islam dan mempunyai nilai budaya yang indigenist (asli). Kelompok ini diwakili oleh budaya pendidikan pesantren. Pesantren termasuk bukan satu-satunya lembaga pendidikan Islam dan tradisi ini salah satu dari beberapa aliran Islam Indonesia masa kini yang tentunya bersaing dengan model tradisi Islam lainnya. Ada paradoks pada tradisi pesantren, di satu sisi ia berakar kuat di bumi Indonesia dan di sisi yang lain ia berorientasi internasional dengan Makkah sebagai pusat orientasinya. Tradisi internasional ini ditunjukkan dengan tradisi kitab kuning jelas-jelas bukan berasal dari budaya lokal Indonesia. Semua kitab klasik yang dipelajari berbahasa Arab dan sebagian besar ditulis sebelum Islam tersebar di 
Indonesia. Pola khas pesantren sebagai lembaga pendidikan juga mencerminkan pengaruh asing dan bahkan kemungkinan mempunyai pengaruh asing. Ia menyerupai madrasah di Timur Tengah dan tradisi India. Tidak ada data yang pasti kapan pesantren pada awalnya berdiri. Data yang ada menunjukkan adanya tanda-tanda hubungan timbal balik antara intelektual muslim Indonesia dengan Makkah pada abad ke 16 hingga abad ke 19. Bukti keberadaanya adalah kitab-kitab klasik berbahasa Arab dipelajari pada abad 16. Beberapa kitab pada zaman itu sudah diterjemahkan ke dalam bahasa Jawa dan Melayu, sementara beberapa pengarang Indonesia telah menulis kitab-kitab dalam bahasa tersebut dengan gaya dan isi yang serupa dengan kitab-kitab ortodoks. Kitab-kitab klasik berbahasa Arab impor yang menopang tradisi keilmuan pesantren ini ditulis pada abad ke 10 sampai dengan 15 M. Agaknya tidak ada data dan sumber yang pasti keberadaan perkembangan pesantren secara spesifik sebelum abad ke $19 \mathrm{M}$.

Terlepas dari perdebatan sejarah kemunculan pesantren, catatan yang terpenting adalah adanya akulturasi budaya yang ditunjukkan pesantren dengan mempertahankan budaya dan tetap bersandar pada ajaran dasar normatif Islam yang berkembang dan bertahan selama berabad-abad. Pesantren memang khas pendidikan yang membumi di Indonesia. Ada beberapa istilah yang ditemukan dan digunakan untuk menunjuk jenis pendidikan ini. Di Jawa termasuk Sunda dan Madura umumnya dipakai isatilah pesantren atau pondok atau pondok pesantren, di Aceh dikenal istilah dayah atau rangkang atau meunasah sedang di Minangkabau disebuut surau. ${ }^{14}$

Secara sosiologis, karena watak pesantren yang akulturatif, pesantren memang terbukti mampu melakukan adaptasi-adaptasi di tengah kemajuankemajuan sains dan tekhnologi yang begitu cepat. Bahkan pesantren mampu menjadi peran sebagai sumbu utama dari dinamika sosial, budaya dan keagamaan masyarakat dengan apa yang disebut masyarakat subkultur. Yaitu miniatur masyarakat kecil dalam lingkup pardikan atau padepokan. Oleh karena itu, apa yang disebut pesantren sebenarnya bukan semata wujud fisik tempat belajar agama dengan perangkat bangunan serta strukur pengelolanya akan tetapi juga masyarakat dalam pengertian luas yang tinggal disekelilingnya dan membentuk pola hubungan budaya, sosial dan keagamaan di mana pola-polanya kurang lebih sama dengan yanng berkembang atau dikembangkan di dalam pesantren. Kebudayaan masyarakat tersebut tidak dapat dibantah memang dipengaruhi oleh pesantren. Walaupun perlu diakui, sekarang pada abad 21 ada pesantren yang menjaga jarak dengan masyarakat sekitar bahkan kadangkala cenderung melakukan intimidasi terhadap masyara- 
kat karena berbeda keyakinan dan cara pandang pemahaman agama antara pesantren dengan masyarakat sekitar. Pesantren model terakhir ini biasanya model pesantren impor dari timur tengah atau negara-negara donor tententu yang mempunyai basis dan misi pengkaderan keyakinan tertentu.

Bangunan budaya institusi yang ada di pesantren yang semula hanyalah diidentifikasi terdiri dari masjid, asrama santri, tempat belajar, rumah kiai dan kurikulum yang tidak baku mengalami perkembangan sebagai dampak dari kemajuan, serbuan budaya luar dan tuntutan profesionalisme. Tidak jarang muncul kritik keberadaan pesantren di tengah serbuan modernisasi budaya pendidikan umum yang kapitalis, misalkan pesantren tidak mempunyai standar karena lebih didominasi oleh muatan-muatan agama, menggunakan kurikulum yang belum standar, memiliki struktur yang tidak seragam, dan menggunakan manajemen yang tidak dapat dikontrol. Kritik ini merupakan hal yang logis dalam era persaingan lembaga pendidikan yang menuntut budaya modern dari Barat. Tentu cukup menyulitkan bagi keberadaan pesantren untuk tetap eksis di tengah budaya pendidikan modern yang prakmatis. Dalam kaca mata pragmatisme pendidikan modern, baca pendidikan model barat, lebih banyak diminati oleh masyarakat karena wataknya yang konsumtif dunia kerja. ${ }^{15}$
Akan tetapi, dengan watak pesantren yang membumi pesantren merespon perubahan modernisasi sesuai dengan dinamika keyakinan dan budaya masing-masing dalam artian ada pesantren yang merespon secara akomodatif dan ada juga pesantren yang merespon secara defensif. Ada pesantren yang merespon dengan merevisi kurikulumnya dan memasukkan semakin banyak mata pelajaran umum dan membuka kelembagaan serta fasilitasfasilitas pendidikannya bagi kependidikan umum. Pada sisi yang lain, ada pesantren yang tetap melakukan peran bertahan dengan mempertahankan substansi pendidikan tradisional. Pada persoalan pertama pesantren merespon kebijakan pendidikan modern (umum) dengan melakukan evolusi pendidikan dengan membuka lembaga pendidikan modern (umum), merupakan dinamika tersendiri setelah merasa tersaingi dengan sistem kelembagaan umum sebagai lembaga modern. Ditemukan dinamika baru semakin banyak pesantren yang mendirikan pendidikan modern di dalam kompleks pesantren masing-masing. Dengan cara ini pesantren tetap berfungsi sebagai pesantren dalam pengertian aslinya, yaitu tempat pendidikan dan pengajaran bagi santri yang ingin memperoleh pengetahuan Islam secara mendalam dan sekaligus madrasah bagi anak-anak di lingkungan pesantren. Sebagian muridmurid pendidikan moderen sekaligus menjadi santri tetap di pesantren yang 
bersangkutan. Dengan mendaftar sebagai santri murid pendidikan modern mereka kemudian mendapatkan pengakuan secara formal dan memiliki akses lebih besar tidak hanya dalam melanjutkan pendidikan, akan tetapi juga dalam lapangan kerja. Dalam perkembangan selanjutnya tidak jarang ditemukan pesantren memiliki lebih banyak murid lembaga modern dari pada santri yang hanya belajar ngaji khusus di pesantren. ${ }^{16}$

Beberapa pesantren tidak hanya mengembangkan eksperimennya mendirikan lembaga-lembaga pendidikan bersistem umum dan madrasi. Beberapa pesantren bahkan mendirikan lembaga-lembaga pendidikan umum. Dengan pengertian, pesantren bukan hanya mendirikan madrasah tetapi juga sekolah-sekolah umum yang mengikuti sistem dan kurikulum modern. Ada juga sebagian madrasah di pesantren yang tidak bersedia mengikuti dan menyesuaikan kurikulumnya dengan pola kurikulum modern, tapi membuat kurikulum sendiri sesuai dengan idealisme pesantren yang bersangkutan. Hal itu dilakukan untuk merespon kebutuhan umat, khususnya berkenaan dengan kebutuhan maasa depan santri untuk bisa mengakses dunia kerja dan pendidikan yang lebih tinggi.

Deskripsi di atas menunjukkan bagaimana respon pesantren dalam menghadapi berbagai perubahan di sekililingnya. Dalam menghadapi semua perubahan dan tantangan itu para eksponen pesantren tidak begitu saja melepaskan dan memfokuskan kelembagaan pesantren menjadi lembaga pendidikan modern Islam sepenuhnya, akan tetapi sebaliknya mereka cenderung mempertahankan kebijakan lembaganya secara hati-hati. Mereka menerima pembaharuan pendidikan hanya dalam skala yang terbatas mampu menjamin pesantren tetap eksis.

\section{Kesimpulan}

Pendidikan secara praktis tak dapat dipisahkan dengan nilai-nilai budaya. Dalam membentuk dan melestarikan kebudayaan sendiri, secara proses mantransfernya yang paling efektif dengan cara pendidikan. Keduanya sangat erat sekali hubungannya karena saling melengkapi dan mendukung antara satru sama lainnya.

Oleh karenanya, pendidikan dalam pembentukan budaya merupakan indoktrinasi sebagai sebuah proses yang dilakukan berdasarkan satu sistem nilai untuk menanamkan gagasan, sikap, sistem berpikir, perilaku dan kepercayaan tertentu. Praktik ini seringkali dibedakan dari pendidikan karena dalam tindakan ini, seseorang yang diindoktrinasi diharapkan untuk tidak mempertanyakan atau secara kritis menguji doktrin yang telah dipelajari. 


\section{Daftar Pustaka}

Abu Zaid, Nasr Hamid, Tekstualitas AlQur'an: Kritik Terhadap Ulumul Qur'an, penerj. Khoiron Nahdliyyin, Yogyakarta: LKiS, 2001.

al-Jabiri, Muhammad Abed, Post Tradisionalisme Islam, penerj. Ahmad Baso, Yogyakarta; LKiS, 2006.

Bizawie, Zainul Milal,"Dialektika Tradisi Kultural: Pijakan Historis dan Antropologis Pribumisasi Islam," dalam Tashwirul Afkar Edisi No. 14 Tahun 2003.

Bruinessen, Martin Van, Kitab Kuning, Tradisi dan Tarekat, Jakarta; Gading Publishing, 2012.

Hanafi, Hassan, Oksidentalisme: Sikap Kita Terhadap Tradisi Barat, penerj. M. Najib Bukhori, Jakarta: Paramadina, 2000

Madjid, Nurcholish, Bilik-bilik Pesantren: Sebuah Potret Perjalanan, Jakarta; Paramadina, 2008.

Kasdi, $\quad 2000$. Fundamentalisme Islam Timur Tengah: Akar Teologi. Kritik Wacana dan Politisasi Agama". Jurnal Tashwirul Afar. Lakpesdan NU Jakarta. No. 3.

Mubarak, Zaki, Genealogi Islam Radikal di Indonesia, Jakarta; LP3ES, 2009.

Muhtarom, Ali, Ideologi dan Lembaga Pendidikan Islam Transnasional di Indonesia, Jakarta; Zahir Publishing, 2019.

Mun'im DZ, Abdul, "Mempertahankan Keragaman Budaya," dalam
Tashwirul Afkar, Edisi No, 14 Tahun 2003.

Rahman, Imdadun dkk.,"Islam Pribumi: Mencari Wajah Islam Indonesia," dalam Tashwirul Afkar Edisi 14 Tahun 2001.

Rahman, M. Imdadun, Islam Pribumi, Jakarta; Erlangga, 2004.

Thahir, Lukman S., Harun Nasution (19191998): Interpretasi Nalar Theologis dalam Islam, Yogyakarta: Disertasi PPs. IAIN Sunan Kalijaga Yogyakarta, 2003.

Verdiansyah, Very, Islam Emansipatoris: Menafsir Agama Untuk Praksis Pembebasan, Jakarta: P3M, 2004.

Yasid, Abu, Paradigma Baru Pesantren, Yogyakarta; Diva Press, 2010. 